緊急気道確保と救急蘇生

一麻酔科医が耳鼻咽喉科医に期待するもの一

東京慈恵会医科大学麻酔科学講座

木山秀哉

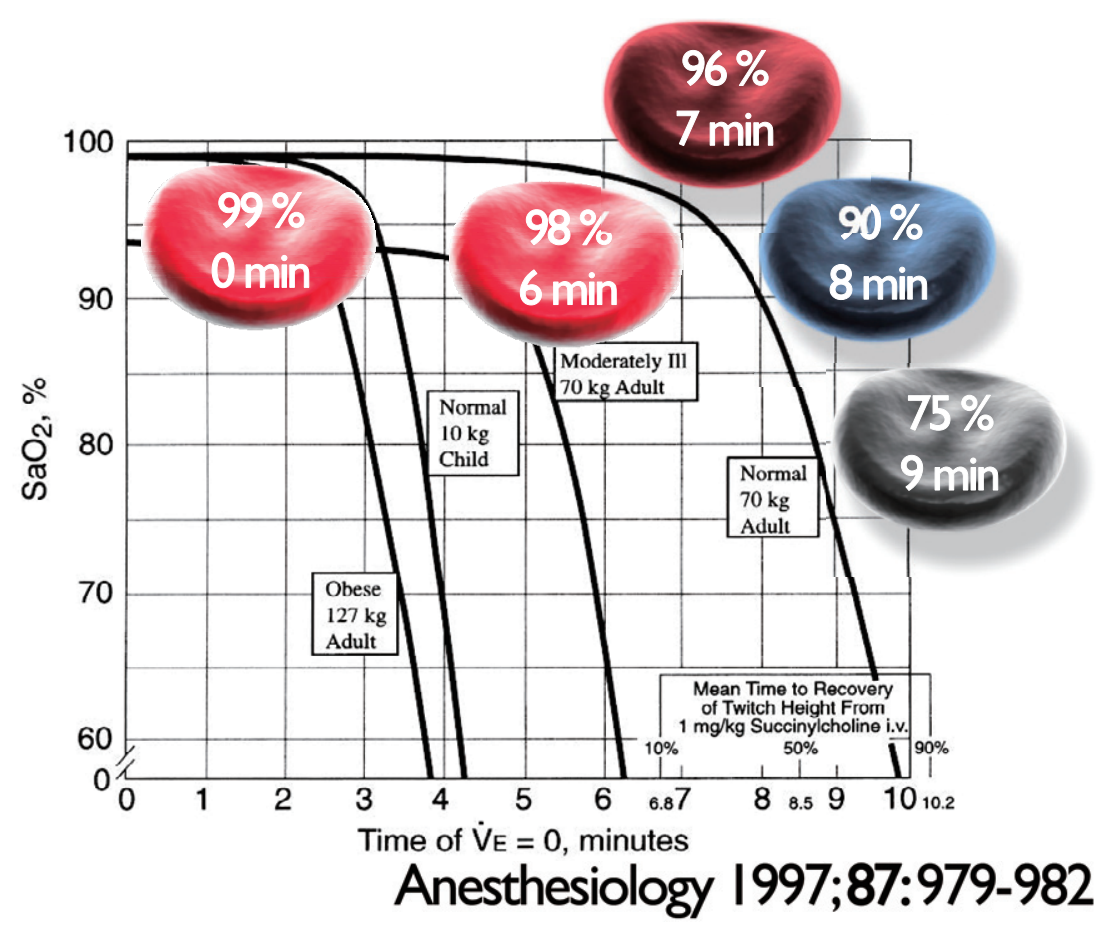

図 1 無呼吸になった場合の酸素飽和度低下シミュレーション

1. ヘモグロビン酸素飽和度 $S_{\mathrm{p}_{\mathrm{O}_{2}}}$ のピットフォール

$S_{\mathrm{p}_{\mathrm{O}_{2}}}$ は非侵襲的, 連続的に酸素化を評価できるパラメ ーターであるが，解釈には注意を要する，肺胞内酸素分 圧 $P_{\mathrm{A}_{\mathrm{O}}}$ は次式で求まる:

$$
P_{\mathrm{A}_{\mathrm{O}_{2}}}=\left(P_{\mathrm{B}}-P_{\mathrm{H}_{2} \mathrm{O}}\right) \times \mathrm{F}_{\mathrm{I}_{2}}-\frac{P a_{\mathrm{CO}_{2}}}{\text { R.Q. }}
$$

$P_{\mathrm{B}}$ : 大気圧（およそ $\left.760 \mathrm{mmHg}\right)$

$P_{\mathrm{H}_{2} \mathrm{O}}$ : 飽和水蒸気压 $\left(\right.$ 体温 $37^{\circ} \mathrm{C}$ で $47 \mathrm{mmHg}$ )

$$
\mathrm{Pa}_{\mathrm{CO}_{2}} \text { : 動脈血二酸化炭素分圧 }
$$$$
\text { R.Q. : 呼吸商（約 } 0.8 ）
$$

$\mathrm{F}_{\mathrm{I}_{2}}=0.5$, 二酸化炭素の体内貯留 $\left(\mathrm{Pa}_{\mathrm{CO}_{2}}=60 \mathrm{mmHg}\right)$ を想定して数值を代入すると,

$$
P_{\mathrm{A}_{2}}=(760-47) \times 0.5-\frac{60}{0.8}=281[\mathrm{mmHg}]
$$

肺胞気動脈血酸素分圧較差 $A \mathrm{a} D_{\mathrm{O}_{2}}$ が正常值 $(10 \mathrm{mmHg}$ 以下)ょり大きくても, 動脈血酸素分圧 $P_{\mathrm{a}_{\mathrm{O}_{2}}}$ は $200 \mathrm{mmHg}$ 以上になるため酸素投与下では通常 $S_{\mathrm{p}_{\mathrm{O}_{2}}}$ は $100 \%$ にな る. $P_{\mathrm{a}_{2}}$ が $60 \mathrm{mmHg}$ を下回ると $S_{\mathrm{p}_{2}}$ は急速に低下す る. 図 1 は健康成人, 肥満成人, 小児等が無呼吸になっ た場合の $S_{\mathrm{p}_{2}}$ 変化シミュレーションである ${ }^{1)}$. 体重 $70 \mathrm{~kg}$ の健康成人は呼吸停止から 7 分半経過すると $S_{\mathrm{p}_{\mathrm{O}_{2}}}$ は95\%を下回り，その後はわずか 1 分半で $75 \%$ まで低下 する. 一方, 肥満患者や健康な小児は, 呼吸が停止して $2 \sim 3$ 分後には $S_{\mathrm{p}_{\mathrm{O}_{2}}}$ が急速に低下し始める.つまり現 在 $S_{\mathrm{p}_{\mathrm{O}_{2}}}$ が正常值であっても，必ずしも患者の呼吸が良 好に保たれている証拠ではなく, 今後も $S_{\mathrm{p}_{\mathrm{O}_{2}}}$ が安定し て正常範囲内に維持されることを保証するものでもな い. $S_{\mathrm{p}_{2}}$ のみで呼吸状態を判断, 特に今後の状態を推測 することは不可能である. 


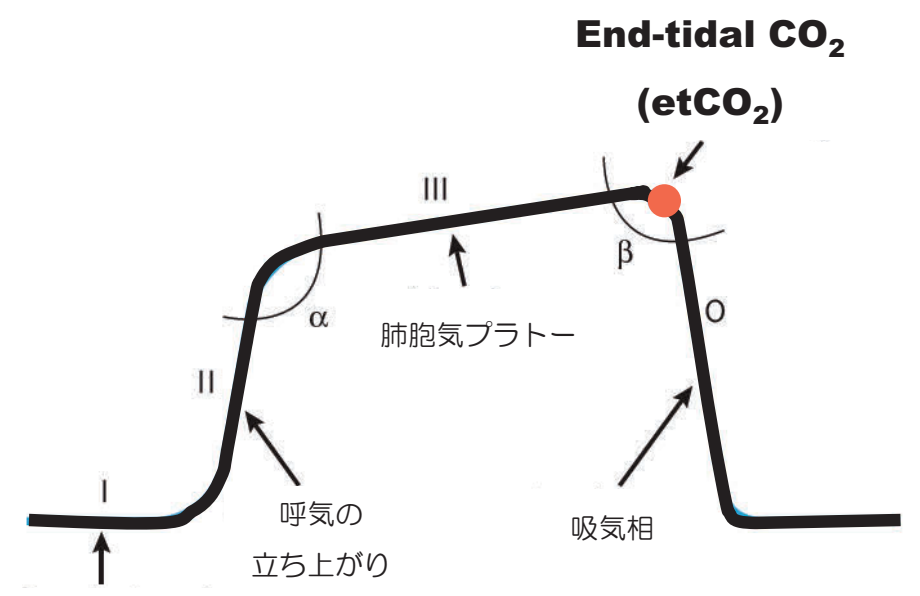

基線（正常値 $=0 \mathrm{mmHg}$ )

図 2 カプノグラム

\section{2. 呼吸（換気）できているか?（カプノグラム）}

患者の自発呼吸で有効なガス交換が行われているか否 かは，呼気中の二酸化炭素を測定，描記するカプノグラ 厶が有用な情報を与えてくれる。代謝産物の $\mathrm{CO}_{2}$ は静 脈血流に乗って右心系に還流，肺動脈血流で肺に運ばれ て呼気中に排出される。つまり呼気 $\mathrm{CO}_{2}$ は代謝, 循環, 換気，気道の総合的指標である。気管抻管あるいは声門 上器具で気道確保している場合, カプノグラム描出は容 易である。呼気終末 $\mathrm{CO}_{2}$ 分圧 (end-tidal $\mathrm{CO}_{2}$ ) は動脈 血二酸化炭素分圧 $\mathrm{Pa}_{\mathrm{CO}_{2}}$ をある程度反映する。 一方, 確 実な気道確保が行われていない場合は $\mathrm{CO}_{2}$ サンプリン グチューブを患者の口元または鼻孔近くに置いて測定す る. End-tidal $\mathrm{CO}_{2}$ の值自体は $\mathrm{Pa}_{\mathrm{CO}_{2}}$ と相関しないが, 呼吸数の連続的，非侵襲的モニ夕として利用できる。炎 症やアナフィラキシーで上気道の浮腫・狭窄が急速に進 行する場合, $S_{\mathrm{p}_{\mathrm{O}_{2}}}$ の低下を認めてから対処するのでは時 機を逸する. 呼吸数, end-tidal $\mathrm{CO}_{2}$, カプノグラムは急 性気道閉塞が切迫する患者のモニタリングとして有用で ある。図 2 は正常なカプノグラムである。第 0 相で吸気 が始まり急速に $\mathrm{CO}_{2}$ 分圧が低下して第 I 相に続く。第 II 相が呼気排出の開始，第 III 相が肺胞気の呼出である. 第 III 相終末值が呼気終末 $\mathrm{CO}_{2}$ 分圧である。通常 II 相と III 相， III 相と 0 相の成す角度（それぞれ図 2 中の角 $\alpha$, $\beta ）$ は $90^{\circ}$ に近い。 $\alpha$ が鈍角で第吕相が右肩上がりになる 場合，呼気の排出障害を示す所見である.

\section{3. 局所麻酔薬中毒の治療（Lipid Rescue）}

耳鼻咽喉科の手術部位である顔面，頭頸部は血流が豊 富なため，局所麻酔薬が血管内に注入される危険性が大 きい. 局所麻酔薬中毒について十分な知識を持つ必要が ある。

1）局所麻酔薬中毒発症の認識

・患者の意識レベルが突然変化（興奮あるいは意識消 失）する，痤攣は必発ではない.

-循環系所見：徐脈，伝導ブロック，心静止，無脈性 電気活動, 心室性不整脈など.

・これらの変化は局所麻酔薬注入中に生じることも, 投与後しばらく経ってから起こる場合もある.

2) 即時の対応

・局所麻酔薬の投与中止.

・助けを呼ぶ。

-気道確保， $100 \%$ 酸素投与，必要なら気管抻管し て人工呼吸.

- 静脈確保

・抗けいれん薬投与（ミダゾラム，チオペンタール， プロポフォール).

3）治療

自己心拍があり，循環が保たれている場合：血圧低 下，徐脈には通常どおりの対処.

循環虚脱（心停止）の場合：

- 直ちに心肺蘇生 (胸骨圧迫, 人工呼吸, $\mathrm{AED}$ 装着) を開始する。

- 脂肪乳剂の静脈内投与（Intravenous Lipid Emulsion therapy : ILE) ${ }^{2)}$ 


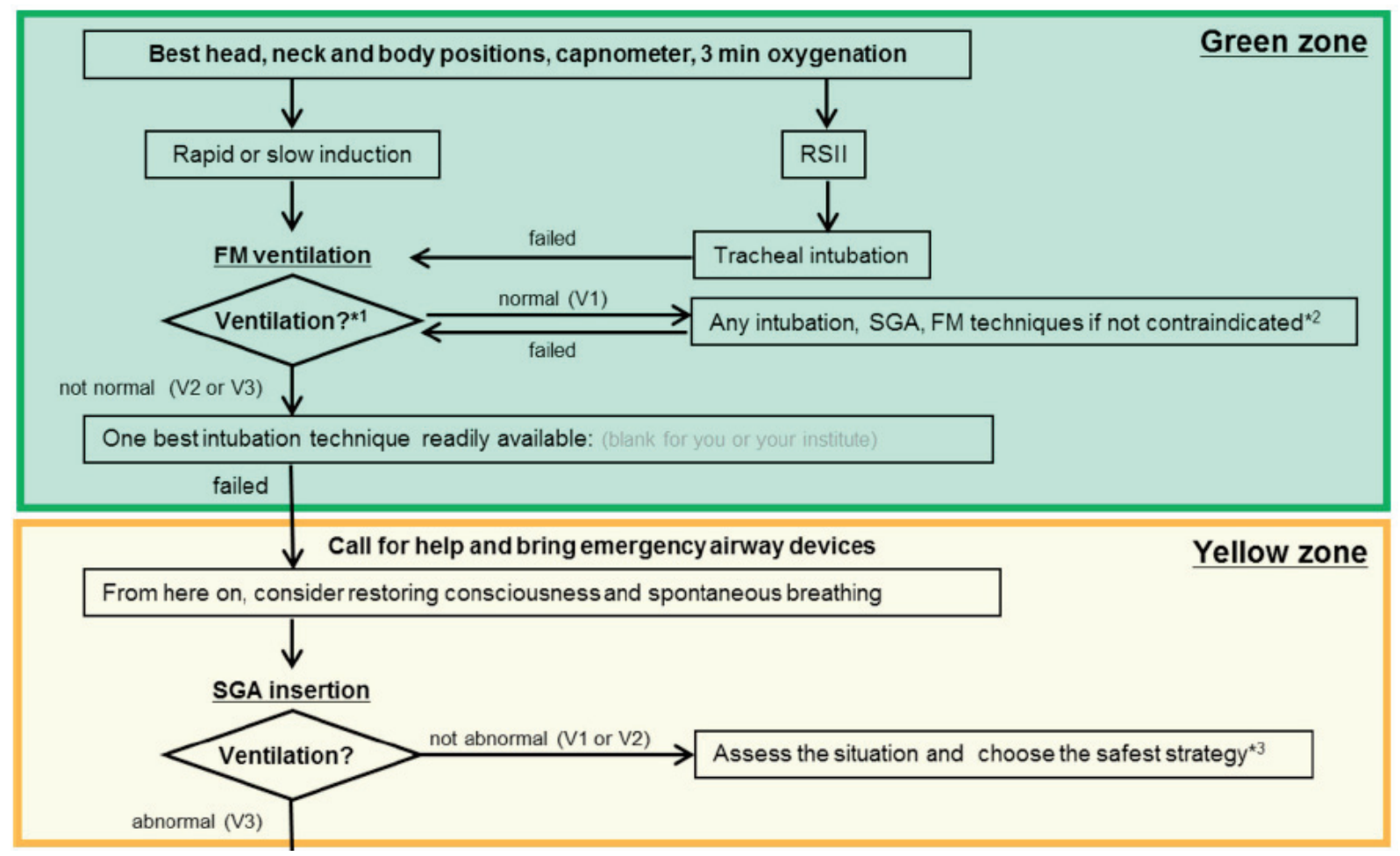

図 3-a 日本麻酔科学会＼cjkstart気道管理アルゴリズム（Green \& Yellow Zone）

局所麻酔薬中毒を疑つたら直ちに：

20\%イントラリピド ${ }^{\circledR}$ (またはイントラリポス $\left.{ }^{\circledR}\right) 1.5$ $\mathrm{mL} / \mathrm{kg}$ を 1 分かけて静脈内投与し，同時に $15 \mathrm{~mL} / \mathrm{kg} / \mathrm{h}$ で持続静脈内投与を開始する.

その 5 分後:

循環動態が不安定な場合，5分間隔で 2 度ボーラス (1. $5 \mathrm{~mL} / \mathrm{kg})$ 投与を追加し, 持続投与速度を 2 倍に増 やす $(30 \mathrm{~mL} / \mathrm{kg} / \mathrm{h})$.

$20 \%$ イントラリピド ${ }^{\circledR}\left(\right.$ またはイントラリポス $\left.{ }^{\circledR}\right)$ の 最大投与量は $8 \mathrm{~mL} / \mathrm{kg}$ である.

\section{4. 日本麻酔科学会気道管理アルゴリズム（JSA-AMA）}

2014年秋，日本麻酔科学会は気道管理アルゴリズム (Japanese Society of Anesthesiologists Airway Management Algorithm；JSA-AMA）を公表した ${ }^{3)}$ 。麻酔科医が 気道確保できない状況で協力を要請される耳鼻咽喉科医 も JSA-AMAの要点を理解することが望ましい.

JSA-AMA は気道確保の手順を緑, 黄, 赤のゾーンに 分ける(図 3-a, 3-b).
Green Zone ではマスク換気の状態をカプノグラムと 一回換気量に基づき，V1 (正常換気), V2 (換気不十分), V3（換気不能）に分ける，胸郭の動きや，マスク内面 が呼気で曇る所見は換気の可否判断の指標にはならな い. V3 では数分以内に重度の低酸素血症に陥る可能性 が高い.V2 またはV 3 の場合，一度だけ気管挿管を試 みる。挿管操作を繰り返すと上気道の浮腫や出血を来し て急速に換気不能になる。抻管に失敗した場合, Yellow Zoneに移行する。この段階で声門上器具（Supraglottic Airway；SGA）挿入を試みる. SGA 扦入後も換気不能 （V3）なら Red Zoneに入る。頸部を触診して輪状甲状 膜を同定し，緊急キットを使用して輪状甲状膜穿刺ある いは切開を行う。しかし緊急事態で輪状甲状膜穿刺／切 開を複数回行った経験がある麻酔科医はそれほど多くな い. 耳鼻咽喉科医に至急の応援が要請されるのは，この ような低酸素症が急激に進行する場面である，低酸素症 による致命的脳障害を回避するために迅速な外科的気道 確保が求められる. 


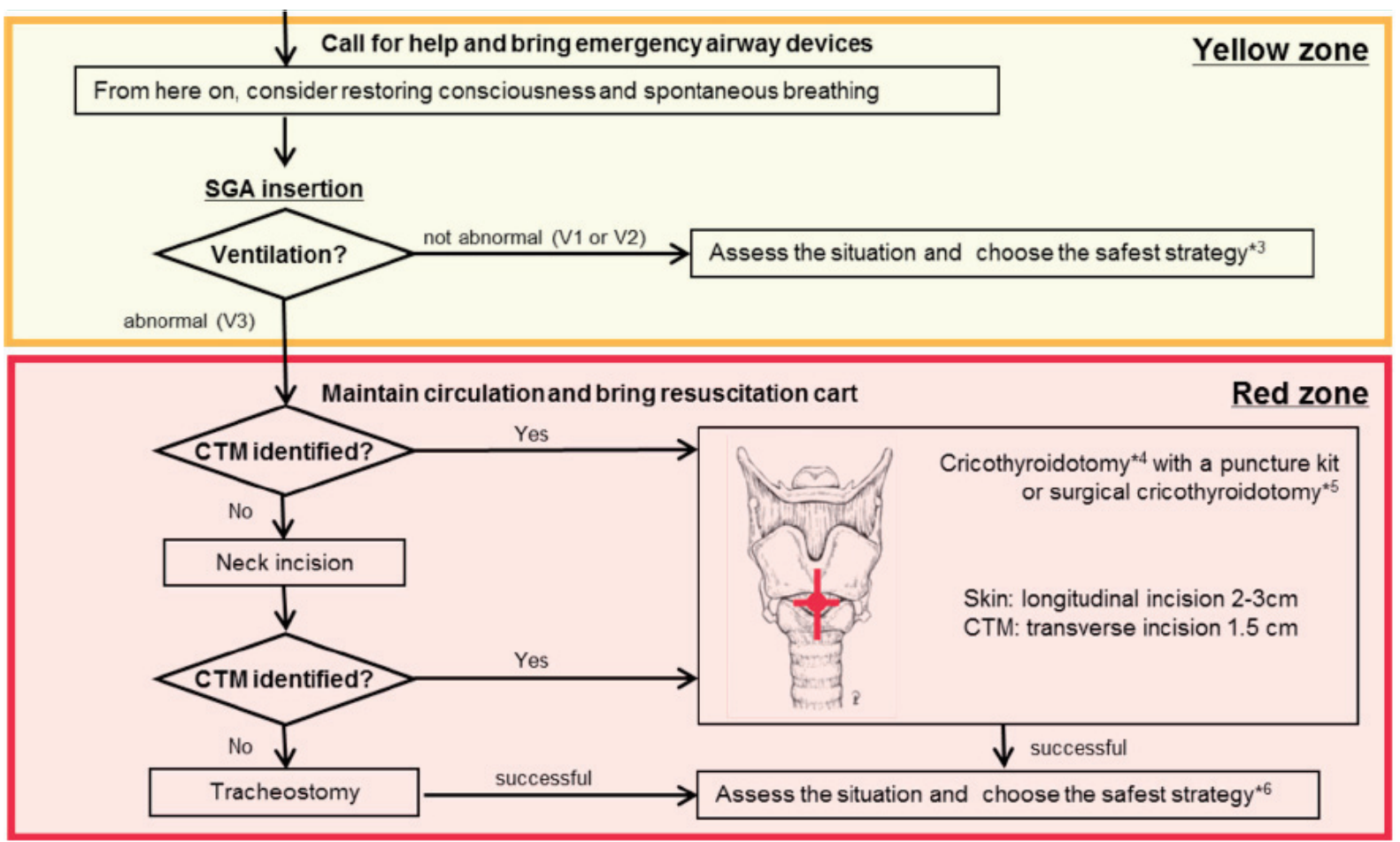

図 3-b 日本麻酔科学会＼cjkstart気道管理アルゴリズム（Yellow \& Red Zone）

文献

1) Benumof JL, Dagg R, Benumof R: Critical hemoglobin desaturation will occur before return to an unparalyzed state following $1 \mathrm{mg} / \mathrm{kg}$ intravenous succinylcholine. Anesthesiology 1997 ; 87 : 979-982.

2) http ://www.lipidrescue.org/, 参照 (2015-03-10).
3) JSA airway management guideline 2014 : to improve the safety of induction of anesthesia. J Anesth 2014; 28: 482-493.

連絡先 $\overline{\mathrm{T}} 105-8461$ 東京都港区西新橋 3-25-8 東京慈恵会医科大学麻酔科学講座 木山秀哉 